\title{
Foraminiferal paleodiversity and paleoenvironments at the NE coastal plain of Buenos Aires province (Argentina) during the Mid-Holocene sea level highstand
}

The Holocene

$1-13$

(C) The Author(s) 2020

Article reuse guidelines:

sagepub.com/journals-permissions DOI: |0.|I77/095968362096|5|| journals.sagepub.com/home/hol (9SAGE

\author{
Angelica Ballesteros-Prada, ' (D) Mariel Luengo, 2,3 \\ Isabel Vilanova, ${ }^{4}$ Enrique Fucks ${ }^{2,3}$ and Emiliana Bernasconi'
}

\begin{abstract}
In this investigation, we carried out a Mid-Holocene paleoenvironmental reconstruction based on fossilized benthic foraminifera, retrieved from sedimentary deposits located in Bahía Samborombón coastal plain. A total of 38 species, grouped into 19 genera, were identified. The assemblage, constituted mainly by Buccella peruviana (d'Orbigny), Cribroelphidium poeyanum (d'Orbigny), Ammonia parkinsoniana (d'Orbigny) and Ammonia tepida (Cushman), indicate predominantly abnormal marine conditions, characterized by low oxygen levels between ca. 6880-6640 and $5600-5430$ yrs cal. BP. During this interval, a quantitative analysis carried out on the assemblages as well as indexes suggest found three different paleoenvironments. The first one, occurring ca. 6880-6640 yrs cal. BP, was a brackish environment with low oxygenation levels and low bottom energy. Then, ca. 6500-6250 yrs cal. $\mathrm{BP}$, an environment with more marine influence, increased oxygen levels and higher energy prevailed. This higher oxygenation could be related to the flow of seawater into the area during the Mid-Holocene sea-level highstand. The third paleoenvironment developed ca. 5590-5430 yrs cal. BP, was under a gradual transition back to a brackish environment with low oxygen levels as well as low energy.
\end{abstract}

\section{Keywords}

benthic foraminifera, Mid-Holocene, paleoenvironmental changes, sea level highstand

Received I5 January 2020; revised manuscript accepted 27 August 2020

\section{Introduction}

The Río de la Plata estuary and the coastal area of the northeastern Buenos Aires province, along with the neighboring coastal plains, were intensely affected by the postglacial sea level fluctuations, particularly during the last maximum marine transgression (e.g. Aguirre and Whatley, 1995; Cavallotto et al., 2004; Codignotto and Aguirre, 1993; Colado et al., 1995; Cortelezzi, 1993; Fidalgo et al., 1973; Fucks et al., 2010; Isla, 1989; Isla et al., 2000; Parker, 1990; Schnack et al., 2005; Violante and Parker, 2000, 2004) among others

One of the greatest effects of the RSL changes occurred in the coastal plain between $35^{\circ}$ and $36^{\circ} \mathrm{S}$, in a $140 \mathrm{~km}$ semicircular bay named as Bahía Samborombón. This bay emerged during the upper Pleistocene in response to interactions between eustatism, marine, coastal, and river dynamic factors (Violante et al., 2001).

Regarding the relative sea level (RSL) changes during the Holocene, the analysis of the RSL database revealed that the RSL rose to reach the present level at or before $c a$. $7000 \mathrm{yrs}$ cal. BP, with the peak of the sea-level highstand $c a$. $+4 \mathrm{~m}$ between $c a .6000$ and 5500 yrs cal. BP (depending on the statistical method used) or at $c a .7000$ yrs cal. BP according to the ICE-6G model prediction, gradually falling after this time to the present position (Prieto et al., 2017). These RSL variations can be better understood by the study of coastal plains, especially salt marsh sediments which are useful archives for interpreting the environmental changes related to the different positions of RSL during the Holocene. These places are open sedimentary systems influenced by many factors that affect sedimentary continuity (removing or redistributing sediments), like

\footnotetext{
'Instituto de Investigaciones en Biodiversidad y Medioambiente (INIBIOMA), Consejo Nacional de Investigaciones Científicas y Tecnológicas-Universidad Nacional del Comahue (CONICETUNCOMA), San Carlos de Bariloche, Río Negro, Argentina ${ }^{2}$ Centro de Estudios Integrales de la Dinámica Exógena, Universidad Nacional de La Plata (CEIDE-UNLP), La Plata, Argentina ${ }^{3}$ Comisión Nacional de Investigaciones Científicas y Técnicas (CONICET), Buenos Aires, Argentina

"Museo Argentino de Ciencias Naturales "Bernardino Rivadavia" (MACN)-Consejo Nacional de Investigaciones Científicas y Tecnológicas (CONICET), Ciudad Autónoma de Buenos Aires, Buenos Aires, Argentina
}

\section{Corresponding author:}

Angelica Ballesteros-Prada, Instituto de Investigaciones en Biodiversidad y Medioambiente (INIBIOMA), Consejo Nacional de Investigaciones Científicas y Tecnológicas-Universidad Nacional del Comahue (CONICET-UNCOMA), Quintral 1250, San Carlos de Bariloche, Río Negro R8400FRF, Argentina.

Email: amballesterosprada@comahue-conicet.gob.ar 


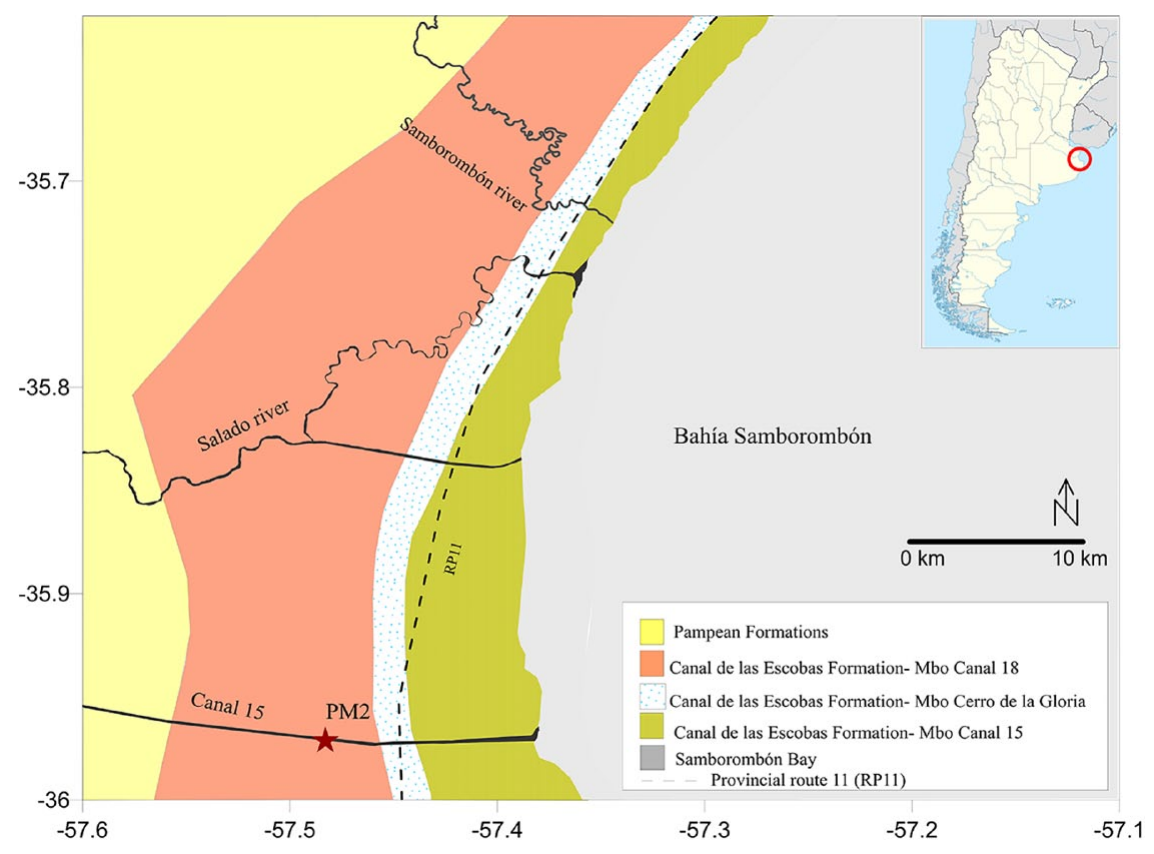

Figure I. Geological map showing the continental sector of Bahía Samborombón (Modified from Fucks et al., 20I0). Red circle indicates the study area and the red star shows the localization of PM2 sequence.

tidal currents and storm waves. The marine deposits of the sequences are grouped stratigraphically under the name of the Canal de Las Escobas Formation, which has four Members: Destacamento Río Salado, Canal 18, Cerro de la Gloria and Canal 15 (Fucks et al., 2010).

In particular, the member Canal 18 has been considered as restricted marginal marine deposits behind coastal barriers (Richiano et al., 2012), or as tidal plain conditions in open environments, which was deactivated from the barrier with the storms ridges (Fucks et al., 2010). The sedimentary sequences from this area have a stratigraphic continuity and high fossiliferous wealth, which gave rise to the development of different depositional environments during the Holocene, such as coastal barriers, beach ridges, tidal flats, and lagoons. These sedimentary sequences represent key archives for reconstructing the environments and their geomorphological history, in particular, those related to Holocene sea-level changes.

Numerous investigations have been carried out in Bahía Samborombón in order to understand and interpret the environmental changes related to sea-level fluctuations since the LGM. In this regard, Aguirre (1990, 1993, 1994a, 1994b) determined the associations of marine benthic mollusks (bivalves and gastropods) of the late Quaternary in the northeast of Buenos Aires province. Other investigations based on palynology established the evolution of the plant communities and the environments since ca. 7800 years BP. (Vilanova and Prieto, 2012).

Concerning the study of foraminiferal assemblages, their distribution and abundance in a specific environment are controlled by physical, chemical and environmental parameters such as temperature, salinity, nutrient concentration, dissolved oxygen content, depth, and substrate features (Armstrong and Brasier, 2008; Murray, 2006). The analysis of foraminifers contributes with the knowledge of biodiversity; which is very useful for interpreting coastal and shelf marine environments. Bertels-Psotka and Laprida (1998a, 1998b) and Laprida (1997, 1998) characterized the marine paleoenvironments established in the NE Buenos Aires province, and determined a restricted marine environment based on the analysis of foraminifera and ostracods. Besides, Laprida and Bertels-Psotka (2003) analyzed the taxonomy and taphonomy of the Holocene foraminifera from Bahía Samborombón, and Laprida et al. (2011) conducted an environmental comparison based on the analysis of modern and fossil associations. More recently, Luengo et al. (2018) integrated the foraminiferal information with other data from other indicators (e.g. pollen and non-pollen palynomorphs) that allowed recognizing paleoenvironmental changes during the late Holocene for the central Bahía Samborombón central area. However, in order to obtain more precise data regarding foraminiferal diversity and the environmental conditions for this microfauna, further research is needed in order to understand the complex of foraminiferal paleoenvironments and ecological conditions.

The objective of the present study is to provide the paleodiversity and paleoenvironments information occurring during the Mid-Holocene, based on a high resolution analysis of the benthic foraminifers from a sedimentary sequence retrieved from the NE coastal plain of Buenos Aires province. These results will contribute to more detailed and specific data to the paleoenvironmental reconstruction of Bahía Samborombón central area during the Mid-Holocene.

\section{Environmental setting}

\section{General characteristics}

Bahía Samborombón is located in the easternmost region of the province of Buenos Aires, Argentina. It extends from Punta Piedras $\left(35^{\circ} 27^{\prime} \mathrm{S}, 56^{\circ} 45^{\prime} \mathrm{W}\right)$ to the north, to Punta Rasa $\left(36^{\circ} 17^{\prime} \mathrm{S}\right.$, $56^{\circ} 46^{\prime} \mathrm{W}$ ), and about $100 \mathrm{~km}$ to the south. It has a variable width; its widest part reaches approximately $32 \mathrm{~km}$. It is characterized by shallow waters that do not exceed the isobaths between 3.5 to $5 \mathrm{~m}$. It constitutes an area of interaction between terrestrial and aquatic ecosystems, where waters of the Río de la Plata get mixed with the Atlantic Ocean, creating particular ecological conditions that harbor a great biodiversity (Fundación Vida Silvestre Argentina, 2013) (Figure 1). In addition, it is a sector of great interest for Quaternary paleoenvironmental reconstructions because its evolution has been related to sea level variations, especially during the Holocene. The central area of Bahía Samborombón is characterized by extensive saltmarshes which are mainly regulated by tidal flows and topography. These, in turn, also determine the dynamics and salinity of both surface and ground water (Boorman, 2003; Carol et al., 2009; Luengo et al., 2018). These saltmarshes have two main zones, low and high, which are different in terms 
Table I. PM2 radiocarbon dates (from Luengo, 2019).

\begin{tabular}{|c|c|c|c|c|c|}
\hline Level $(\mathrm{cm})$ & $\left({ }^{14} \mathrm{C}\right.$ yr BP $)$ & $\begin{array}{l}\text { Calibrated age weighted aver- } \\
\text { age/yrs cal. BP (I- } \sigma \text { interval) }\end{array}$ & Laboratory $n$. & Material & $\begin{array}{l}\text { Depositional } \\
\text { environment }\end{array}$ \\
\hline PM2 72-73 & $5153 \pm 40$ & $5596-5432$ & D-AMS 030366 & Bulk organic matter & Tidal plain \\
\hline PM2 127-I28 & $5950 \pm 120$ & $6503-6249$ & LP-3275 & Mactra isabelleana & \\
\hline PM2 25I-252 & $6300 \pm 100$ & $6882-664 \mid$ & LP-3327 & Mactra isabelleana & \\
\hline
\end{tabular}

of frequency of tidal floods, and sedimentological and floristic composition (Bértola et al., 1998; Cagnoni, 1999) The low-marsh is flooded daily and its extension is bound by the limits of influence of the daily tidal regime. The high marsh is irregularly flooded and its upper limit is conditioned by the extent of the flood produced by extremely high tides (Cagnoni, 1999). Among the high and low zones, a different pattern of vegetation composition signals a transitional middle zone.

Tidal, topography, and climatic features. The coastal plain has almost no slope $(\sim 0.01 \%)$ and an average elevation of $1.6 \mathrm{~m}$ above mean sea level (Carol et al., 2008; Luengo et al., 2018). The tidal range has very small amplitude, between 0.46 and $0.52 \mathrm{~m}$ according to the Servicio de Hidrografía Naval (2002) and it is thus considered microtidal. There is a horizontal gradient of marine water salinity that ranges from 5 psu to $20-25 \mathrm{psu}$, from Punta Piedras to Punta Rasa (Guerrero et al., 1997), respectively. Inland from the coast, several sectors can be identified: waters with and without sediments, tidal plains, saltmarshes and the Pampa plain (Bértola et al., 1998). Numerous factors, such as continental water inputs, rainfall recharge and evaporation, establish the hydrochemical and isotopic conditions of groundwater (Carol et al., 2013).

The climate is temperate, sub-humid to humid, with an annual average temperature of $16^{\circ} \mathrm{C}$ and maritime influence decreasing to the west and south-west. The annual average precipitation is $950 \mathrm{~mm}$, but it is concentrated mostly during the summer (Garreaud et al., 2009). The most representative winds are those from N, NE, E, and SE. The SE winds annually generate a precipitation event called Sudestada that significantly affects the region by pushing waters inland. These events promote unusually high tides and restrict the flow of water in artificial canals and streams, causing flooding in large areas. Another event is ENSO which is typically associated with anomalously wet conditions in the southeastern South America at decadal and multidecadal scale (Garreaud et al., 2009).

\section{Geological and geomorphological background}

In the continental sector of Bahía Samborombón, sea level fluctuations originated most of the geomorphologies and sediment deposits, such as tidal channels, and marshes, among others. In particular, the deposits that correspond to the transgressiveregressive phases of MIS 1 were grouped under different formal units within the Canal de Las Escobas Formation, composed by four members: Destacamento Río Salado, Cerro de la Gloria, Canal 18 and Canal 15 (Fidalgo et al., 1973; Fucks et al., 2010).

During the last sea-level highstand, the deposition of the Members Destacamento Río Salado and Canal 18 took place, which consisted of muds with flaser and wavy stratification, and muds and sands with parallel lamination of sub to intertidal environments. After the deposition of these units, during the sea-level fall, coastal ridges formed, giving rise to Cerro de la Gloria Member, which is a beach environment composed by sand and organic material (Fucks et al., 2010). Also, to the east of the ridges, the sediments of Canal 15 Member were deposited related to the sea level fall. This member represents tidal plain environments that resemble a marsh in response to an intense coastal progradation and the formation of cheniers (Luengo et al., 2018).

\section{Materials and methods}

\section{Sampling and chronology of the sedimentary sequence}

A $258 \mathrm{~cm}$ sedimentary sequence (PM2) was collected on the right margin of Canal 15 ( $\left.35^{\circ} 58^{\prime} 16.4^{\prime \prime} \mathrm{S}, 5^{\circ} 28^{\prime} 58.7^{\prime \prime} \mathrm{W}\right)$ (Figure 1). In the laboratory, texture, color, sedimentary structure, and the presence of gastropods and bivalves, complete or fragmented, were identified and described. The sequence was subsampled at $1 \mathrm{~cm}$ resolution.

The chronology of the analyzed section was based on three radiocarbon dates, two on Mactra isabelleana shells and one on bulk organic matter (Table 1). The $M$. isabelleana valves were entire and without signs of reworking. Radiocarbon dates were calibrated using the program Calib Rev. 7.0.2 (Stuiver and Reimer, 1993) against the Southern Hemisphere curve, SHCal13 (Hogg et al., 2013) and the Marine13 curve (Reimer et al., 2013).

\section{Foraminiferal analysis}

Levels were selected for analysis every $5 \mathrm{~cm}$ obtaining 54 samples. They were washed with tap water through a sieve with a mesh size of $63 \mu \mathrm{m}$ (Tyler Screen System No. 230) and dried at room temperature. From the dry residue, between 100 and 300 individuals were selected when possible. Identification at the generic and suprageneric level was based on Loeblich and Tappan (1992) and Sen Gupta (1999), whereas for smaller categories, we used Boltovskoy et al. (1980) and Luengo et al. (2018) were also used. The most representative specimens were photographed with a scanning electron microscope (Philips SEM 515) at Centro Atómico (Bariloche, Argentina); and stored at the repository of Universidad Nacional del Comahue (Río Negro province, Argentina), under numbers UNC-PMIC 237 to 251.

The proportions of agglutinated, porcelanaceous and hyaline individuals were calculated. Concentration (individuals per gram of dry sediment) and species richness (S) were estimated. In addition, the indexes of diversity such as Shannon-Wiener $(\mathrm{H})$ and Fisher's alpha $(\alpha)$ were calculated in order to better constrain the environmental conditions ( $\alpha$, only in samples with more than 100 individuals).

In addition, dissolved oxygen levels in seawater were calculated using the benthic foraminiferal oxygen index or Kaiho index (BFOI) (Kaiho, 1994, 1999) based on foraminiferal morphotype characteristics.

The microhabitat (infaunal/epifaunal) was also determined to infer eutrophication in the environment. Infaunal individuals, such as biserial and triserial forms, reflect low-oxygen environments, whereas epifaunal specimens are associated with highoxygen environments (Bernasconi et al., 2009; Sen Gupta and Machain-Castillo, 1993).

The Ammonia-Elphidium Index (AEI) has been used in the literature to study regions affected by hypoxia due to large contribution of organic matter (Eichler et al., 2012; Pregnolato et al., 2018; Sen Gupta et al., 1996; Sen Gupta and Platon, 2006). Both 


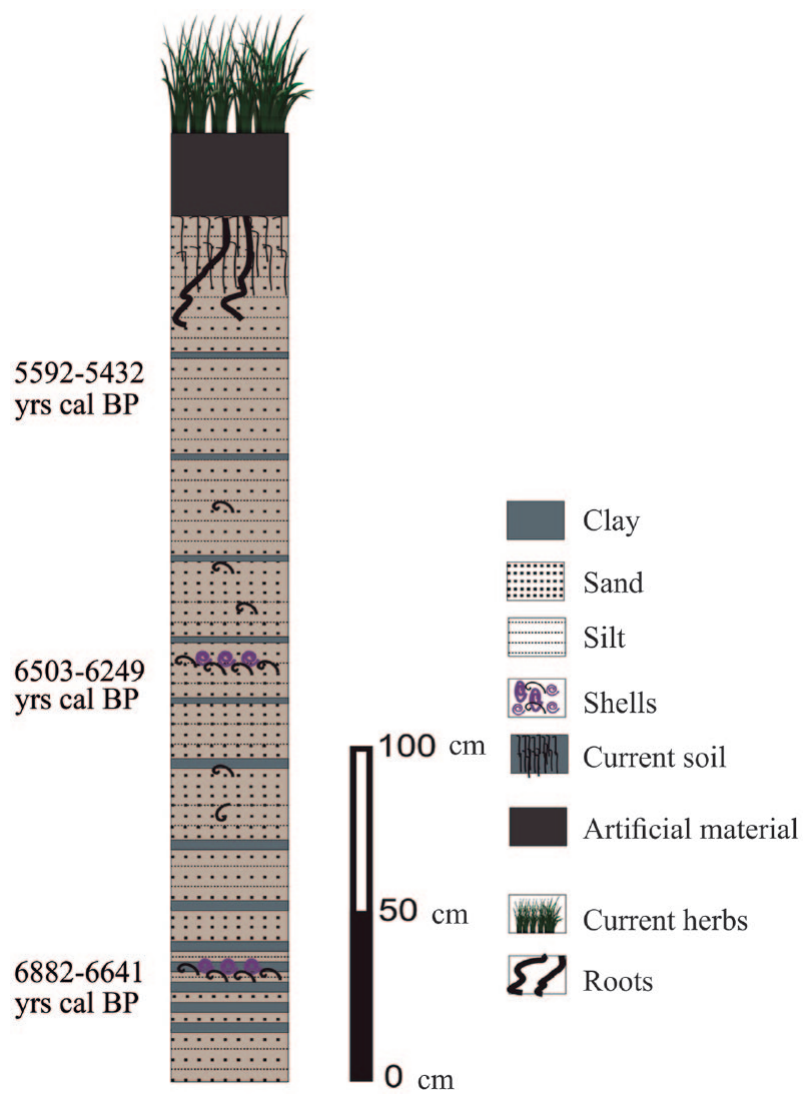

Figure 2. Graph showing ${ }^{14} \mathrm{C}$ radiocarbon age of sediments and the PM2 lithological description (modified from Luengo, 2019).

of these genera are resistant to hypoxic conditions, but Ammonia genus is more resistant than Elphidium. This index is calculated by $\mathrm{AEI}=[\mathrm{NA} /(\mathrm{NA}+\mathrm{NE})] \times 100$, where NA and NE are the numbers of Ammonia and Elphidium individuals, respectively.

Also, a taphonomic analysis was performed in order to evaluate the degree of preservation of foraminifers. In this analysis, four taphonomic groups were defined based on Brandt (1989) and Laprida and Bertels-Psotka (2003): (A) well preserved shells, lacking at most the last chamber, (B) "Black" shells with fillings in the chambers and/or with a polished coating in dark brown or black color, (C) broken or fragmented shells, and (D) polished or reworked shells.

\section{Statistical analysis}

A clustering analysis was carried out to determine changes in foraminiferal assemblages throughout the sedimentary sequence, zonation was defined by stratigraphically constrained cluster analyses by applying Coniss software, included in the statistical package Tilia 2.6.1 (Grimm, 2004). For this analysis, only species with a relative abundance equal to or greater than $2 \%$ were considered. Standardized Euclidian distance was applied as the distance coefficient, and data transformation by standardization to mean 0 and 1 typical deviation (SD) was used (Grimm, 2004). The Palaeontological Statistical program (Past), version 3.25, was used to calculate diversity indexes (Hammer et al., 2001).

\section{Results}

\section{Lithological features and PM2 chronology}

At the base of the sequence, the alternation of layers of clay and fine sand to silt predominates, with thicknesses varing between 2 and $10 \mathrm{~cm}$, and with parallel stratification and brown to greenish brown colors. At $252 \mathrm{~cm}$, a layer of high fossiliferous

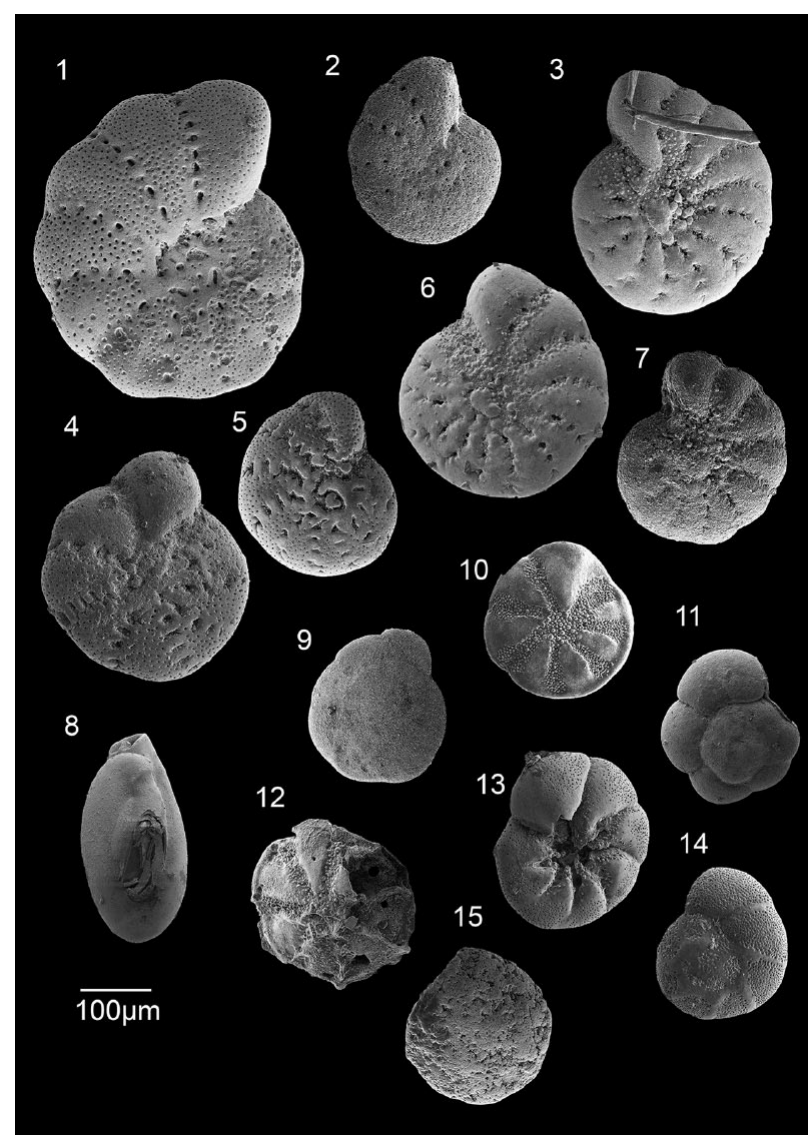

Figure 3. I, 2 Cribroelphidium poeyanum (UNC-PMIC. 237238); 3, 6, 7 Elphidium galvestonense (UNC-PMIC. 239-24I); 4,5 Cribroelphidium gunteri (UNC-PMIC. 242-243); 8 Quinqueloculina milleti (UNC-PMIC. 244); 9 , I0 Buccella peruviana (UNC-PMIC. 245246); II Ammonia tepida (UNC-PMIC. 247); 12 Buccella peruviana, broked (UNC-PMIC. 248); I3, I4 Ammonia parkinsoniana (UNCPMIC. 249-250), and I5 Buccella peruvina, reworked (UNC-PMIC. 25I).

concentration was observed with an age of 6880-6640 yrs cal. BP. The alternation of layers of clay and sand are repeated throughout the entire sequence with thickness variations. However, at $160 \mathrm{~cm}$, there is a predominance of sandy-silt layers of greater thickness interspersed with layers of clay material. At $128 \mathrm{~cm}$, the presence of a fossiliferous layer was observed with an age of 6500-6250 yrs cal. BP. Above this level, a sandy-silt sedimentary package of $\sim 65 \mathrm{~cm}$ thick, and light brown color was found, with small gravelsized carbonate concretions scattered throughout the unit and with an abundance of Tagelus Plebeius (Lightfoot, 1786). From the $79 \mathrm{~cm}$ toward the top, there are silt-sandy sediments, interspersed with layers of clay of low thickness, light brown colors and without the presence of mollusks. At $72 \mathrm{~cm}$, the calibrated radiocarbon age obtained from organic matter was 5600-5430 yrs cal. BP. The sequence culminates with a structured, dark brown soil, approximately 10 to $15 \mathrm{~cm}$, above which lies a homogeneous layer of uncovering material that originates from the development of Canal 15, which took place at the beginning of the 20th century (Figure 2).

\section{Micropaleontological analysis}

A total of 54 samples were analyzed, seven of which, located at the top of the profile, were barren of macrofossils. In the remaining 47 samples, a total of 38 species grouped into 19 genera were identified, which mainly correspond to the Order Rotaliida. The most abundant species were Buccella peruviana (d'Orbigny), Cribroelphidium poeyanum (d'Orbigny), Ammonia tepida (Cushman), and 


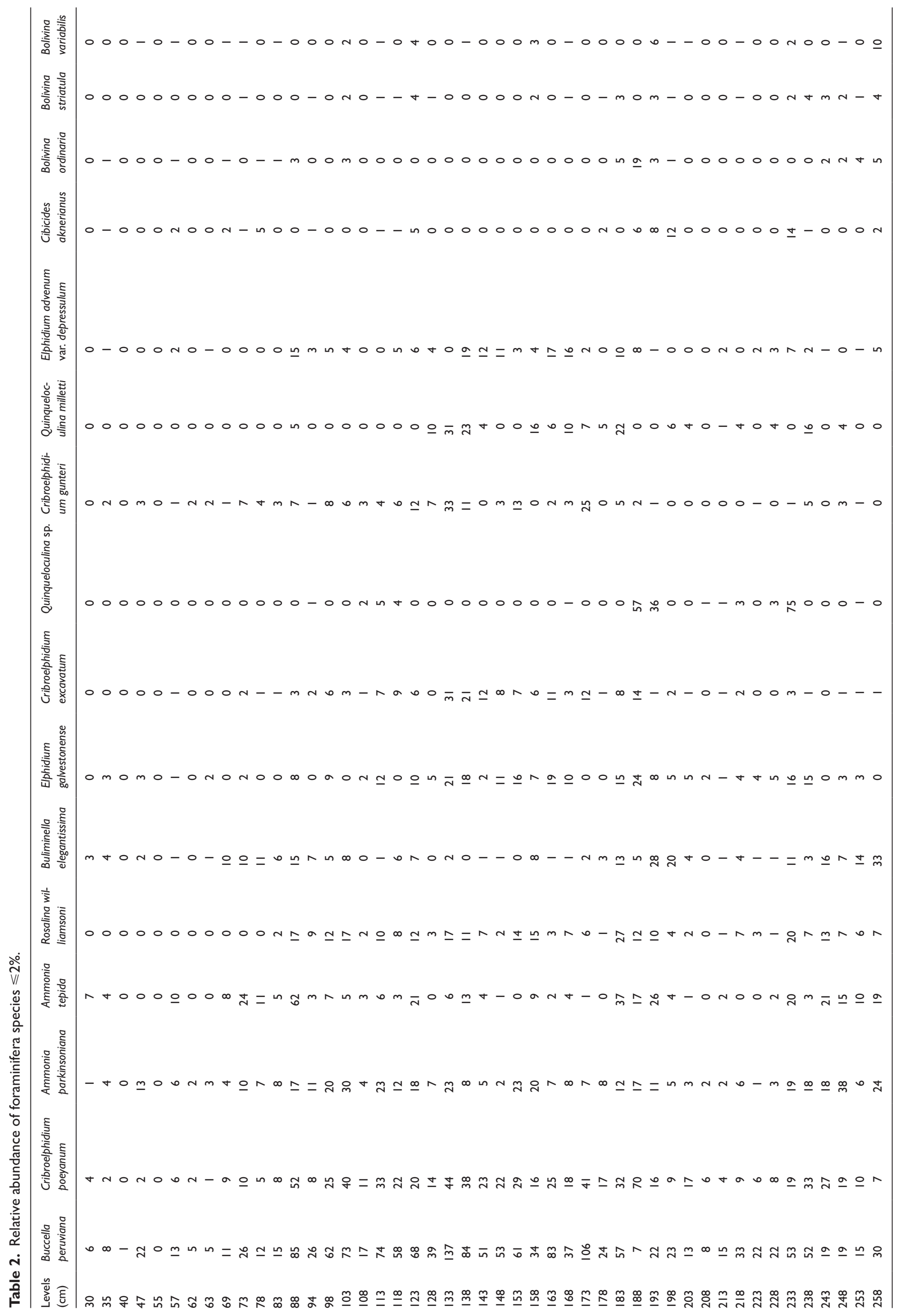




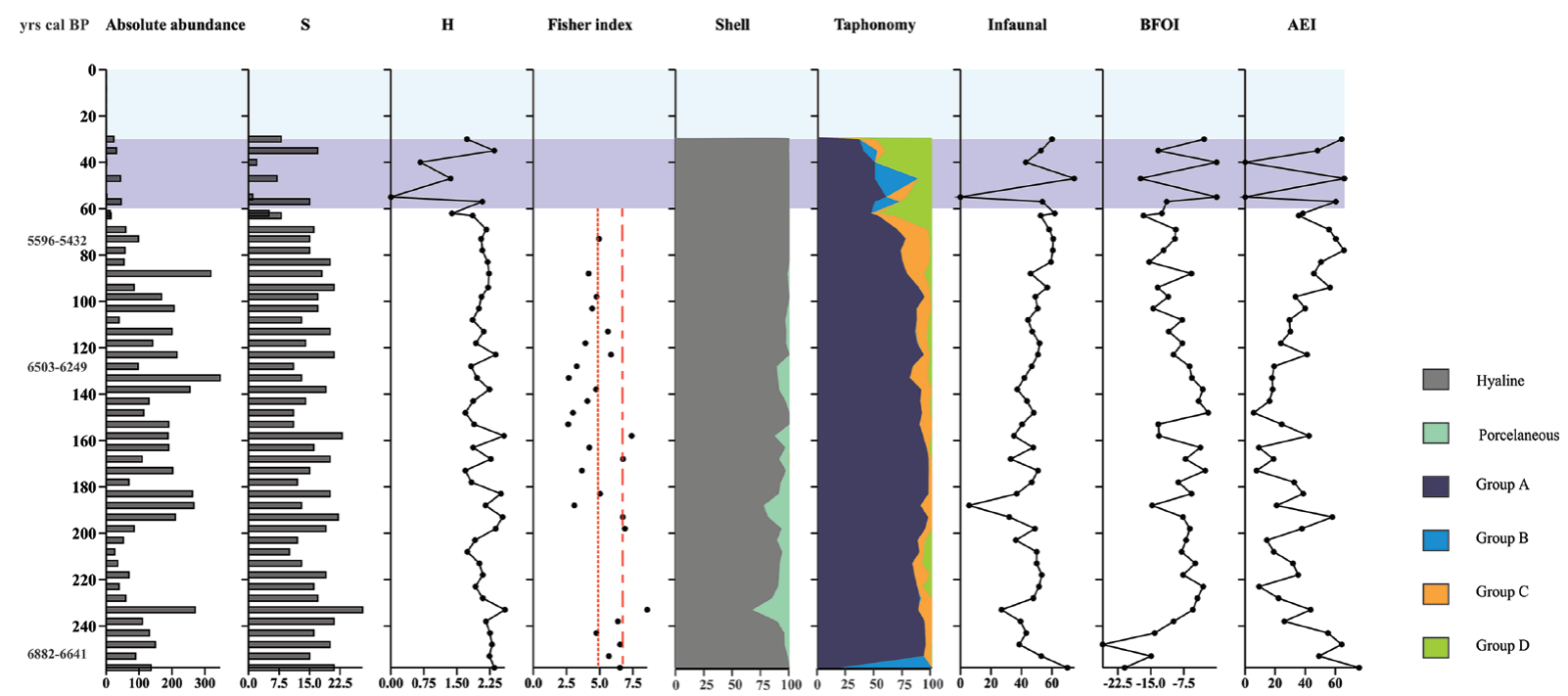

Figure 4. Abundance, species richness (S), type of shell (P: Porcelanaceous), Shannon-Wiener $(H)$ and Fisher alpha indexes $(\alpha)$; Taphonomic groups (A) Well preservation. (B) Reworked. (C) Fragmented. (D) dark color or with signs of piritization. Proportion of infaunal, BFOI (Benthic Foraminifera Oxic Index) and AEI (Ammonia-Elphidium Index) values distribution.

Ammonia parkinsoniana (d'Orbigny). These species were present in more than $90 \%$ of the levels (Figure 3; Table 2).

The abundance of benthic foraminifers varied between 1 and 346 individuals. The highest values were observed in the middle part of the sequence and the lowest values at the top. The species richness (S) varied between 1 and 28 species along the sequence; these values were very homogeneous (between 10 and 20) except in the range between $62 \mathrm{~cm}$ and the top, where the values were clearly low (Figure 4).

No agglutinated shells were observed along the profile; whereas hyaline shells predominated $(>67 \%)$ and porcelanaceous individuals were present in lower proportions $(<32 \%)$. The hyaline shells were mostly represented by $B$. peruviana, $C$. poeyanum, A. tepida, and A. parkinsoniana. Porcelanaceous shells were mainly represented by species of the genus Quinqueloculina. The sequence ranging from the base to $240 \mathrm{~cm}$ displayed low values of this type of shells $(6 \%-4 \%)$, followed by an increase $(<19 \%)$ between 233 to $158 \mathrm{~cm}$, and then a reduction $(<11 \%)$ from 158 to $88 \mathrm{~cm}$ (Figure 4). $\mathrm{H}$ values between $0.6(40 \mathrm{~cm})$ and $2.6(158 \mathrm{~cm})$ were observed, presenting a decrease in diversity from the base to the top (Figure 4). Fisher's alpha index varied between 2.6 at $153 \mathrm{~cm}$ and 9.3 at $158 \mathrm{~cm}$ (Figure 4).

In general, the individuals found throughout the entire sequence were well preserved (taphonomic group A). Between $1 \%$ and $28 \%$ of the specimens were found fragmented (taphonomic group $\mathrm{C}$ ). At the top of the sequence, a high percentage $(28 \%-90 \%)$ of shells were detected with signs of abrasion and/or rework (taphonomic group D). The percentage of colored or dark shells was between $25 \%$ and $75 \%$ (taphonomic group B), (Figure 4). The proportion of infaunal individuals varied from $27 \%$ to $75 \%$, while the BFOI range from -25 to 0 . The values of the AEI along the sequence ranged from 0 to 75.8 (Figure 4).

\section{Foraminiferal zonation}

The clustering analysis rendered a dendrogram where three zones can be identified: The PM2-Z1 zone stretched from the base of the section to $238 \mathrm{~cm}$ depth, and the PM2-Z2 zone was located between 233 and $83 \mathrm{~cm}$, and was divided into two subzones: the PM2-Z2a (233-188 cm) and the PM2-Z2b (183-83 cm). The last zone PM2-Z3 stretched from $78 \mathrm{~cm}$ toward the top of the sequence; these zones are detailed below (Figures 4 and 5).

PM2-Z1 (258-238 cm): the most represented species were $B$. peruviana, C. poeyanum, $A$. parkinsoniana, A. tepida,
B. elegantissima, B. ordinaria and B. striatula. Also, Rosalina williamsoni (Chapman and Parr), Elphidium galvestonense (Kornfeld), Cribroelphidium excavatum (Terquem), Elphidium advenum var. depressulum Cushman, and Bolivina variabilis (Williamson) were found, in lower proportion. The abundances varied between 89 and 149. Between 16 and 25 taxa were identified and the $\mathrm{H}$ values varied between 2.1 and 2.4, while the alpha's Fisher values varied between 4.5 and 8.3. The infaunal species varied between $38 \%$ and $70 \%$, the BFOI ranged between -9 and -26 , and the AEI took values between 26 and 76 .

$P M 2-Z 2 a(233-188 \mathrm{~cm})$ : This zone is characterized by $B$. peruviana, C. poeyanum, A. parkinsoniana, A. tepida, $R$. williamsoni, B. elegantissima, E. gavestonense, C. excavatum, $Q$. milleti, and other species of the genus Quinqueloculina. The abundance varied between 26 and 270. Between 12 and 28 species were determined and the $\mathrm{H}$ values ranged between 1.8 and 2.6, while the alpha's Fisher varied between 3.1 and 8.6. The infaunal species varied between $5 \%$ and $53 \%$, the BFOI between -3 and -14.7 , and the AEI values varied between 9 and 58.

PM2-Z2b (183-83 cm): This zone is characterized by the presence of B. peruviana, C. poeyanum, A. parkinsoniana, $R$. williamsoni, Q. milletti, E. gavestonense, C. gunteri. Also, E. advenum var. depressulum was founded in lower proportion. The abundance varied between 5 and 346. The taxa values varied between 11 and 27, while the $H$ values varied between 1.7 and 2.6, $\alpha$ index between 2.6 and 9.2 and the infaunal species varied between $33 \%$ and $59 \%$, the BFOI values varied between -2.6 and -15 and the AEI ranged between 5 and 56 .

PM2-Z3 $(78-30 \mathbf{c m})$ : This zone is characterized by the presence of B. peruviana, C. poeyanum, A. parkinsoniana, A. tepida and B. elegantissima. B. ordinaria, and B. variabilis were present in low proportion. The abundance varied between 1 and 96 . The taxa identified found were between 1 and 19 , while the $H$ values varied between 0.7 and 2.4. The infaunal species varied between $0 \%$ and $75 \%$ while the BFOI between 0 and -17 , and the AEI took values between 0 and 66 .

\section{Discussion}

The relative sea level variations in the Holocene generated changes in the environments of the Bahía Samborombón. The analyzed sequence (PM2) comprises an age range between $\sim 6880-6640$-yrs cal. BP and $~ 5600-5430$ yrs cal. BP, when the 


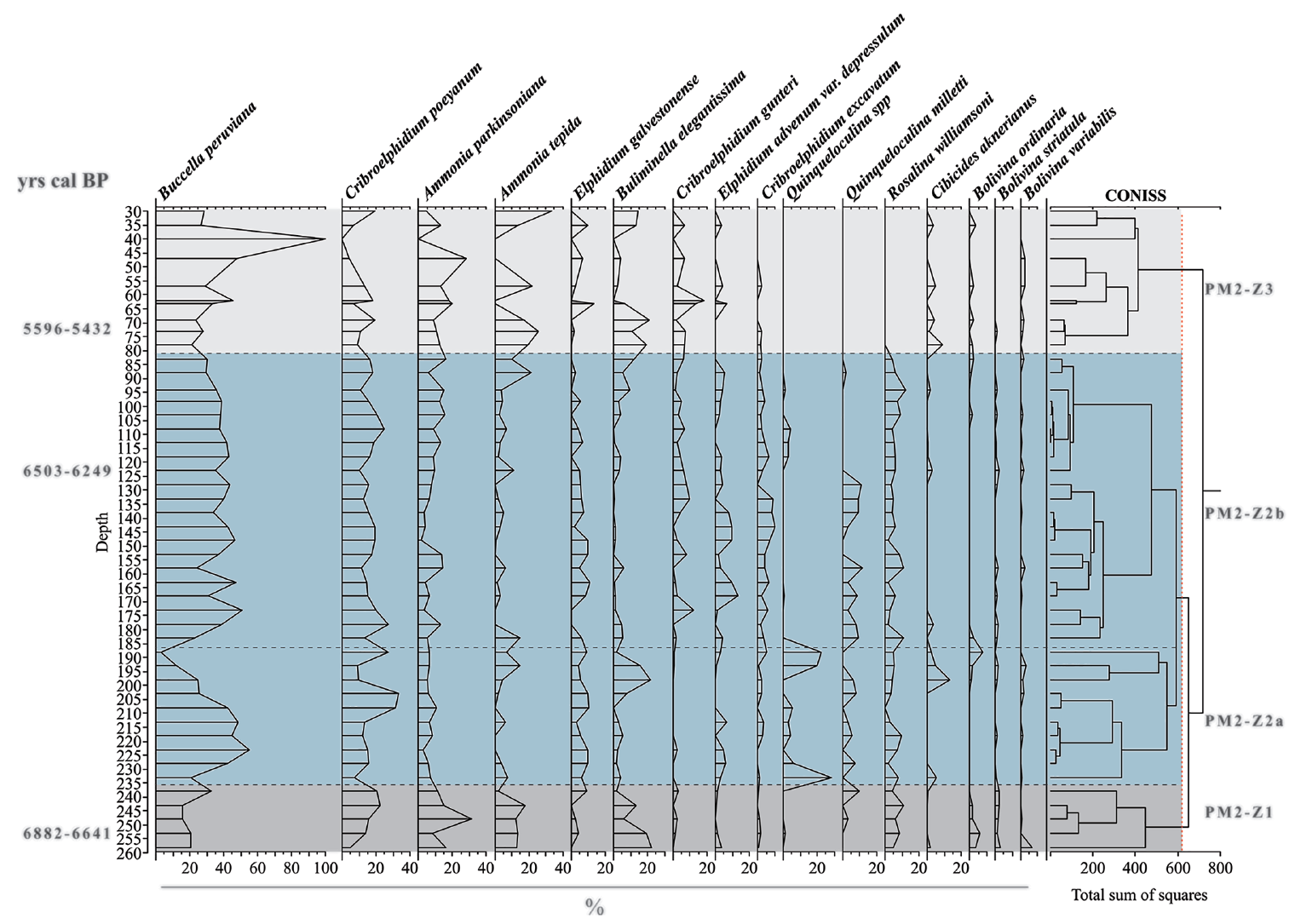

Figure 5. Distribution of the species with $>2 \%$ in at least one sample and cluster analysis showing the recognized zones.

sea level reached the transgressive maximum (Prieto et al., 2017; Violante et al., 2001).

\section{Taphonomy and indexes interpretation}

In general, the shells obtained from the PM2-sequence, were well preserved (group A), although fragmented elements, with altered color were also observed (groups $\mathrm{C}$ and $\mathrm{B}$ ), especially from the level $62 \mathrm{~cm}$ up to the top (Figure 4). This mainly reflects autochthonous assemblages accompanied by some allochthonous elements. At the base of this sequence, the proportion of shells with brown color (group B) increased; which could be the result of diagenetic modifications in the mineralogical composition, as an effect of the partial replacement of carbonates by sulfides or pyrite coating (Martin, 1999). This particular state of preservation might suggest that the shells have been exposed to reducing conditions (Martin, 1999). The idea of an environment with low oxygenation conditions before $\sim 6880-6640 \mathrm{yrs}$ cal. BP is reinforced by the presence of infaunal forms related to their ability to tolerate low oxygen concentrations, high flow of organic matter and low bottom energy as it is the case of the species Bolivina ordinaria, Bolivina striatula, and Buliminella elegantissima (Teodoro et al., 2010).

From 248 to $62 \mathrm{~cm}$, the shells presented a high degree of preservation with a few fragmented shells (group A and C). These characteristics suggest an environment of higher bottom energy since the fragmentation would be reflecting that these elements were exposed to dissolution, rework or transport by the action of tides, waves or other types of currents (Laprida and BertelsPsotka, 2003). Above $62 \mathrm{~cm}$, toward the top of the sequence, a clear decrease in the abundance of foraminifers (45-1 individuals per gram) was observed, and most of shells were of brown color. In addition, a large number of reworked shells found may be reflecting allochthonous origin. In fact, Laprida and BertelsPsotka (2003) suggest that different biostratinomic histories would be indicative of a different origin, that is, they would have a different provenance and not originated in the same place or time. This part of the section was deposited after $\sim 5600-5430 \mathrm{yrs}$ cal. BP, coinciding with the beginning of the sea level regressive phase and the formation of regressive bioclastic beach ridges of $\sim 400$ to $500 \mathrm{~m}$ wide (Luengo et al., 2018). In these pulses of relative sea level fall, there were erosive events from ancient bottom deposits (Codignotto and Aguirre, 1993).

In brackish environments, such as lagoons, estuaries and marshes, assemblages of agglutinated foraminifers predominated for example, Trochammina spp. and Jadammina macrescens; as well as some hyaline forms for example, Ammonia and Elphidium (Ballesteros-Prada and Bernasconi, 2019; Calvo-Marcilese and Pratolongo, 2009). Nevertheless, we did not observe any agglutinated specimens in our Holocene sequence. This situation was also noted by Calvo-Marcilese et al. $(2011,2013)$ and Gómez et al. (2005) in Holocene sedimentary deposits located southwest, in Bahía Blanca estuary (Buenos Aires province); as well as in the central zone of Bahía Samborombón (Laprida and Bertel-Psotka, 2003). This absence of agglutinated forms may be related to taphonomic processes derived from the microbial degradation of organic cements (Berkeley et al., 2007; Goldstein and Watkins, 1999). Moreover, Laprida et al. (2011) mentioned that the dominance of Buccella, Ammonia, and Elphidium could be the result of taphonomic processes that favored the selective preservation of such species. On the other hand, abundance and diversity (S) related to the number of species were variable, with relatively low values throughout the sequence.

Both, abundance and diversity $S$ reached their maximum value at the $233 \mathrm{~cm}$ level with 28 species and 270 individuals. These parameters of abundance and diversity are comparable with those found in the Bahía Blanca estuary by Calvo-Marcilese et al. (2011) and by Laprida and Bertels-Psotka (2003). In addition, Laprida et al. (2011) inferred that the diversity would be remarkably lower in the Holocene than in the present. Several authors relate the low specific diversity of foraminifera to unstable 
conditions in brackish environments such as marshes, lagoons or estuaries, while high values of diversity would indicate normal marine conditions (Boltovskoy and Wright, 1976; Haynes, 1981; Murray, 1991, 2006).

Regarding the Shannon-Wiener $(\mathrm{H})$ diversity, this index takes into account not only the number of species but also the proportion of each species in each sample analyzed (Murray, 1991). According to Buzas and Gibson (1969), the $\mathrm{H}$ values between 0.4 and 0.2 would indicate an environment of high instability, while values higher than 2.4 would indicate a normal marine environment. Along the sequence the Shannon-Wiener $(\mathrm{H})$ diversity values were $<2.4$, with slightly higher values in a few levels. These results suggest unstable conditions along the sequence being distal to normal marine environment. These values are consistent with those reported by Murray (2006) for marshes.

In the case of the alpha Fisher index, it has been proposed as a tool to classify or to determine different environments related to salinity and physiography (Wright, 1972). This index is interesting because it takes into account both the number of specimens and the number of species (Fisher et al., 1943). Initially, Wright (1972) proposes that $\alpha$ values between 5 and 16 describe marine shelf environments of normal salinity, and values between 1 and 5 coastal and hyposaline marine conditions. In turn, Murray (1991) mentioned that values greater than 7 would represent normal conditions of shelf-to-bathyal or hypersaline environments, between 5 and 7 represent shallow shelf environments and lagoons with abnormal salinity, and values less than 5 would suggest hyposaline conditions in general; or hypersaline marginal marine with high dominance of any species. Later, Murray (2006) mentioned that the marginal marine and brackish shelf environments have low $\alpha$ values $(<4)$; however, in normal marine environments and hypersaline marshes $\alpha$ values are higher $(<6)$. Along the sequence, in general, we registered values lower than 7 and a slight decreasing trend of values toward the top, which would generally indicate a hyposaline sedimentary environment. In particular, a greater diversity was found in some of the levels $(248,233,193$, and $158 \mathrm{~cm})$, that agreed with the indices $\mathrm{S}$, and $\mathrm{H}$, which were consistent with a normal marine environment (Figure 4). It is probable that the increase in the diversity of foraminifers at these levels is due to the introduction of shells by suspension that are transported by tides to the tidal plain, and increase in the diversity of dead assemblages (Wang and Murray, 1983). At these levels, fragmented specimens were found with signs of abrasion, coinciding with the presence of epifaunal specimens, such as species of Quinqueloculina and Rosalina.

Besides, the morphology of the benthic foraminifera is related to their preference of microhabitat (Corliss and Chen, 1988). One of the factors that define the microhabitat is the content of dissolved oxygen in the water-sediment interphase (Bernhard, 1986). Therefore, when oxygen levels become a limiting factor, epifaunal forms are the first affected and their abundance decreases (Corliss, 1985; Smart, 2002). These low levels of oxygen on the surface of the sediments are often associated with high productivity, caused by the oxidation of organic matter (Corliss and Chen, 1988). So, at the base of the sequence, high abundance of infaunal specimens $(\sim 70 \%)$ indicates low oxygenation conditions. From $253 \mathrm{~cm}$, the proportion of infaunal specimens decreased $(53 \%-$ $5.6 \%$ ) up to $158 \mathrm{~cm} \mathrm{level,} \mathrm{from} \mathrm{where} \mathrm{a} \mathrm{new} \mathrm{increase} \mathrm{occurred,}$ reaching the maximum value of $75 \%$ toward the top sequence.

Likewise, the values of BFOI along the sequence $(-26$, level: $248 \mathrm{~cm}$ and 0 , level: $40 \mathrm{~cm}$ ) would indicate suboxic conditions between 0.3 and $1.5 \mathrm{~mL} / \mathrm{L}$; showing variations that are in agreement with those determined by the epifaunal-infaunal relationship. A predominance of infaunal species could be expected; however, unstable environments could generate an exception to the basic scheme of the TROX model (Jorissen et al., 1995). Some authors suggest that certain opportunistic epifaunal species are very successful in colonizing empty niches (Barmawidjaja et al., 1992; Gooday, 1993). Jorissen et al. (1995) mentioned that, in the case of seasonal re-oxygenation of anoxic environments, where most of the production of foraminifers is concentrated in a short period, the resulting fauna could be represented by opportunistic species of epifaunal pioneers.

The Ammonia-Elphidium index (AEI) also illustrates oxygenation levels of coastal environments, since both genera are resistant to oxygen reducing conditions (Pregnolato et al., 2018; Sen Gupta et al., 1996; Sen Gupta and Platon, 2006). Nevertheless, the genus Ammonia has greater resistance than the genus Elphidium to tolerate low oxygen conditions, and both are abundant in the coastal zone (Pregnolato et al., 2018). Here, we find high values of the Ammonia-Elphidium index, which suggest low oxygen conditions. As these genera are widely distributed and able to be easily conserved in the fossil record, they become a useful tool to assess the level of oxygenation in paleoenvironments (Sen Gupta and Platon, 2006). The Ammonia and Elphidium genera have been reported in recent foraminifera assemblages in marshes, lagoons, and estuaries (Ballesteros-Prada and Bernasconi, 2019; CalvoMarcilese and Pratalongo, 2009; Laprida et al., 2007).

In this regard, the high AEI values at the lower levels of the profile (49-76) suggest low concentrations of oxygen in the environment. From the $238 \mathrm{~cm}$ level, the AEI values are variable, decreasing toward the $153 \mathrm{~cm}$ level (58.1-7.6), where there is an increase of the oxygenation levels. From $148 \mathrm{~cm}$ the values of this index up to approximately $60 \mathrm{~cm}$, reflected a decrease in oxygenation. However, in addition to oxygen deficiency, the decrease in salinity could raise the AEI level (Karlsen et al., 2000). A gradual increase in salinity could be indicated by the increase in Elphidium and the decrease in number of individuals from Ammonia genus (Brewster-Wingard et al., 1996). Therefore, the AEI works best as a hypoxia marker where there have been no significant historical variations in salinity (Sen Gupta and Platon, 2006). According to Brewster-Wingard et al. (1996), the Ammonia-Elphidium association would indicate oligohaline to mesohaline conditions with salinities of 5 to $18 \mathrm{psu}$. A gradual increase in salinity would be reflected by an increase in Elphidium proportion and a decrease in the number of individuals of the Ammonia genus. In this context, toward the base, the increase of Ammonia could respond to low levels of oxygenation; while the increase in Ammonia toward the top of the sequence could be due to the influence of lotic systems, which is consistent with the registered species. Therefore, the increase in AEI values would not be related to a low oxygenation event, but to a low salinity event which is consistent with Bertels-Psotka and Laprida (1998a) for the upper part of the Canal 18 Member.

The last three indices mentioned above (AEI, BFOI, Infaunal) reflected low oxygenation conditions $(0.3-1.5 \mathrm{~mL} / \mathrm{L})$ from approximately $6880-6620$ yrs cal. BP to $5600-5430$ yrs cal. BP. The detected variations suggested a low oxygenation environment before $6880-6620$ yrs cal. BP, probably followed by a reoxygenation event derived from the flow of seawater to the study area. After $c a$. $6500-6250$ to 5590-5430 yrs cal. BP, took place a passage to a less energy and salinity conditions. Subsequently, $c a$. 5600-5430 yrs cal. BP a return to brackish environment with lower oxygen levels was recognized.

\section{Faunal assemblages}

The most abundant benthic foraminiferal species identified throughout the PM2 sequence were Buccella peruviana, Criboelphidium poeyanum, Ammonia parkinsoniana, and Ammonia tepida. Miliolids and biserials forms were recovered in minor percentages and variable distribution along the sequence. These species have been recorded in the Argentinian zoogeographic province, mainly in the North Patagonian subprovince. In terms of the geological age, they have been recorded both in the present (Ballesteros-Prada and Bernasconi, 


$\begin{array}{ll}\text { yrs cal BP } & \begin{array}{l}\text { Palaeoenvironmental } \\ \text { inference }\end{array}\end{array}$

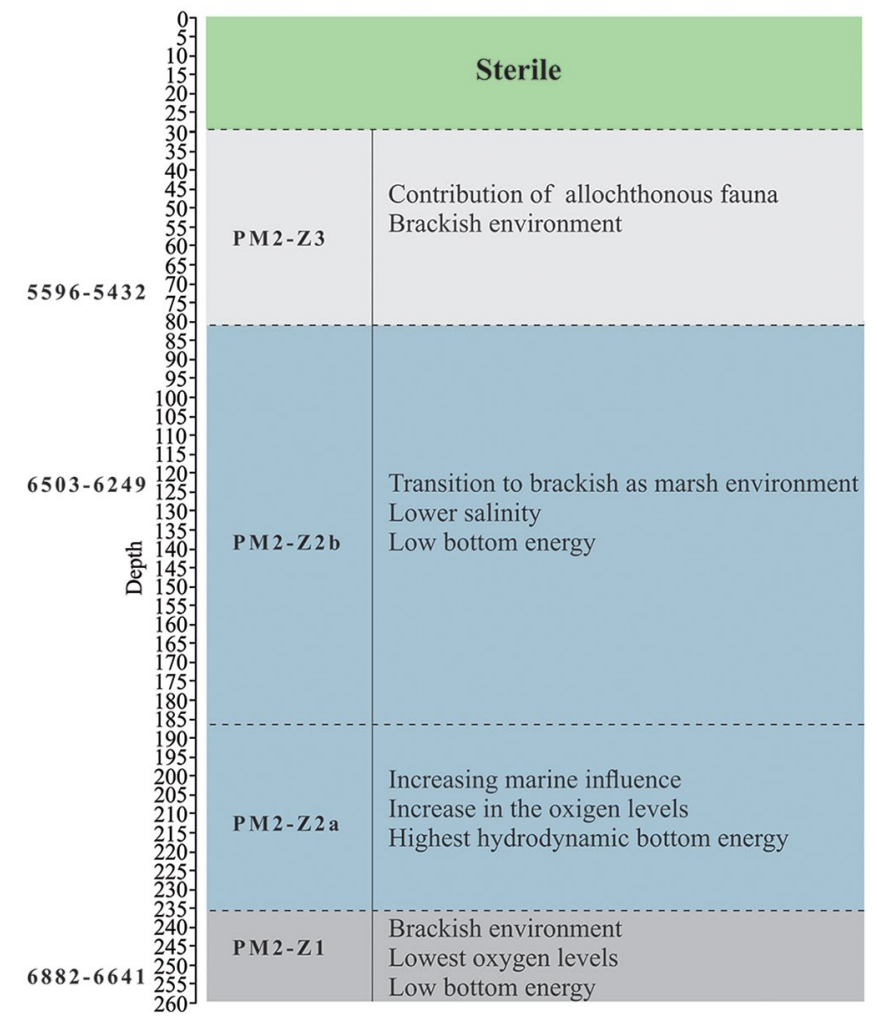

Transgresive stage

Figure 6. Paleoenvironmental reconstruction on the base of the foraminiferal analysis from PM2 sequence.

2019; Bernasconi, 2020; Bernasconi et al., 2018; Bernasconi and Cusminsky, 2020) and in the past, particularly in the Holocene (Cusminsky et al., 2009; Laprida et al., 2007; Laprida and Bertels-Psotka, 2003; Luengo et al., 2018, among others).

B. peruviana has a wide range of distribution: it has been reported in coastal areas, the inner shelf, the bathyal zone and in marine-marginal environments, for example lagoons, tidal plains, muddy intertidal environments, and estuaries (Bernasconi and Cusminsky, 2007 2009, 2015; Calvo-Marcilese et al., 2011; Laprida, 1998; Laprida and Bertels-Psotka, 2003; Márquez et al., 2016).

Species of the genus Elphidium were registered in muddy and sandy sediments of inner shelf, brackish and hypersaline marshes and lagoons (Bernasconi and Cusminsky, 2007, 2015; Murray, 1991). One of the species described here: Criboelphidium poeyanum agrees with the description made by Calvo-Marcilese et al. (2011) for $E$. aff. poeyanum type I, and has been reported in restricted marginal marine environments from Bahía Blanca estuary (CalvoMarcilese et al., 2011), as well as in shallow waters of coastal and inner shelf of Argentina (Alperin et al., 2008). Another species named Criboelphidium gunteri was reported as a dominant species in marshes and lagoons (Murray, 2006). Particularly, in South America, it has been found in brackish waters from Lagoa dos Patos, Brazil; Río Quequén, Argentina (Boltovskoy et al., 1980) and coastal environments of Mar Chiquita, Argentina (Márquez, 2019). Calvo-Marcilese and Pratolongo (2009) also reported these two species, E. aff. poeyanum and $C$. gunteri, in marshes and tidal flats of the Bahía Blanca estuary (Argentina). Elphidium advenum var. depressulum was found in mixohaline waters of Río de la Plata, while Elphidium galvestonense was occasionally found in brackish waters, for example, Lagoa dos Patos. (Boltovskoy et al., 1980).

The genus Ammonia includes specimens that live in muddysandy sediments, typical of brackish marshes and lagoons, and brackish marine environments from inner shelf to upper bathyal waters (Murray, 2006). It is most common in marsh to subtidal sediments with highly variable mud and Total Organic Carbon
(TOC) content. This genus is able to tolerate salinities up to $50 \mathrm{psu}$, and it was thus registered in sites with large salinity variations, including sites with very low salinity (less than $1 \mathrm{psu}$ ) (Koehn-Zaninetti, 1982; Márquez, 2019).

This assemblage along the PM2-sequence was characterized by species of the genera Ammonia and Elphidium, along with Buccella peruviana that is mainly associated with less marine conditions such as estuarine and mash environments (Ishman et al., 1996; Sen Gupta and Barun, 1999). This association was cited for Holocene sediments from the coastal plain of Buenos Aires province, in zones located in close proximity to the study area (Laprida et al., 2007; Márquez, 2019; Márquez et al., 2016) including marsh sediments from Bahía Samborombón (Laprida, 1998; Laprida and Bertels-Psotka, 2003; Luengo et al., 2018); and in brackish sediments from Bahía Blanca estuary (Calvo-Marcilese et al., 2011, 2013).

The assemblages constituted by Buccella peruviana, Elphidium spp., and Ammonia spp. describe a brackish environment along the PM2-sequence. In that context, different authors inferred that the base of the Canal 18 Member is a sedimentary environment of tidal plain conditions in marsh environments (Fucks et al., 2010; Luengo et al., 2018; Richiano et al., 2012). Also, the assemblage is constituted by euryhaline species that are able to tolerate wide salinity ranges. In summary, our results showed a brackish environment such as a marsh or shallow lagoon with variations in relation to the oxygenation and bottom energy levels arising in the central sector of Bahía Samborombón. These variations are detailed below.

\section{Paleoenvironmental evolution}

Based on the micropaleontological analysis and on various indexes, we were able to identify main four stages in the evolution of the environment represented in the sedimentary sequence PM2 from Bahía Samborombón during the Mid-Holocene (Figure 6). 
In the first stage, deposited from $c a .6880-6640 \mathrm{yrs}$ cal. BP (PM2-Z1: 258-238 cm), a brackish environment with low salinity conditions probably prevailed. The great abundance of Ammonia in relation to the proportion of Elphidium and Buccella suggested a brackish environment with the lowest salinity values. Quantitative analysis and the faunal assemblage indicated unstable environmental conditions that differ from the normal marine salinity setting. In addition, the presence of infaunals forms: biserials and triserials such as B. elegantissima, B. ordinaria, and B. striatula reflected a low concentration of disolved oxygen in the environment. Teodoro et al. (2010) recognizes the species $B$. ordinaria, $B$. striatula, and B. elegantissima as species related to low oxygen concentrations. These conditions are in accordance with the results obtained from the Ammonia-Elphidium and BFOI indexes and the epifaunal-infaunal relation.

On the other hand, the sediment plays an important role in the abundance and the distribution of the foraminifers with grain size being one of the most relevant determinant forcing (Hayward et al., 2002; Murray, 2006). In this sense, the presence of these infaunal species could be related with the muddy sediment. In fact, Bernasconi and Cusminsky $(2005,2009)$ and Bernasconi et al. (2009) found the preference for muddy sediment by Buliminella elegantissima and Bolivina spp. On the contrary, the epifaunal species such as Buccella peruviana and Quinqueloculina seminula would be less capable to live in muddy sediment, preferring sandy sediment instead (Bernasconi and Cusminsky 2007, 2015; Bernasconi et al., 2018). Therefore, this zone corresponds to a brackish environment with the lowest oxygen concentration (between 0.3 and $1.5 \mathrm{~L} / \mathrm{mL}$ ) and low bottom energy.

The second stage (PM2-Z2) from 233 to $83 \mathrm{~cm}$, suggested an increase of normal marine conditions and a shallow environment ca. $6500-6250$ and 5590-5430 yrs cal. BP. At the beginning of this stage the increase in the marine influence could be related to the flow of seawater into the area, probably resulted from the transgressive event during the Mid-Holocene. The percentages of B. peruviana and epifaunal species of the genera Elphidium, Cribroelphidium, and Quinqueloculina increased, suggesting higher levels of oxygenation, which are supported by the indexes values that also showing a slight increase in oxygen concentration closer to $1.5 \mathrm{~mL} / \mathrm{L}$ of dissolved oxygen. Several authors consider that proliferation of these species with infaunal microhabitat could be related to their preference to inhabit muddy-sandy sediments (Bernasconi et al., 2018; Bernasconi and Cusminsky, 2020). Teodoro et al. (2010) suggested that the presence of Quinqueloculina spp. such as Quinqueloculina milletti and other individuals, such as $R$. williamsoni, are related to high hydrodynamic bottom environments.

According to Usera and Blázquez-Morilla (1997), the resistance to erosion of shells in the Order Miliolida favors their relative abundance. Alperin et al. (2011) and Bernasconi, 2020) reported that epifaunals as miliolids are associated to sandy sediments and high-energy environments. Genera that get attached to the substrate, such as Quinqueloculina spp. remain at the sites despite water movement or conditions of stress (Goldstein, 2002). Toward the top of the sequence $c a .6500-6250$ yrs cal. BP (from 175 to $123 \mathrm{~cm}$ ), a reduction in the environmental energy was suggested by the increase in abundance of species such as C. excavatum, E. advenum var. depresulum, and C. gunteri, and also to the detriment of miliolids reflecting a decrease in bottom energy in the environment.

From $c a$. 6500-6250 yrs cal. BP, an increase in the abundance of the Ammonia species was observed. Instead, the proportion of Buccella and Elphidium decreased, and individuals of the genus Quinqueloculina were absent. This context and the indexes values revealed a transition to brackish conditions such as in marsh environment.

Finally, the last stage $c a$. 5590-5430 yrs cal. BP was characterized by very low abundance, composed by many individuals whose shells showed signs of abrasion and reworking, probably to transport processes of this allochthonous fauna. A gradual increase in Ammonia spp., a decrease in C. gunteri in particular, as well as in the miliolids individuals suggested a diminution in salinity. Also, it occurred the increasing percentages of B. elegantissima, Bolivina ordinaria and Bolivina striatula were registered. This increase in the infaunal forms is probably due to the presences of muddy sediment that prevails in this upper part of the sequence. In addition, Bernasconi and Cusminsky (2009), Bernhard et al. (1997), Hayward et al. (2002), Sen Gupta and Machain-Castillo (1993), Smart (2002), and Alperin et al. (2011) concluded that some Bolivina, Bulimina and other biserial species are adapted to living in zones with minimum oxygen levels. The increase in these infaunal species together with the data obtained from the indexes would reflect eutrophic conditions with lower oxygenation.

Our results showed paleoenvironmental changes that would be consistent with the RSL rise during the Mid-Holocene, this inference is in agreement with the sea level highstand proposed by several authors for Bahia Samborombón and surrounding areas of the Buenos Aires province (Fucks, et al., 2010; Márquez, 2019; Márquez et al., 2016; Márquez and Ferrero, 2011; Schnack et al., 2005). After this time, it gradually declines to the current position. Recently, Luengo et al. (2018) determined past environmental changes associated to the Late Holocene sea-level fall (last 2700 yrs BP) at Bahía Samborombon, NE coastal plain, characterized by coastal progradation.

\section{Conclusions}

In the analyzed sequence from Canal 18 Member, 38 species corresponding to 19 genera were identified, with predominance of hyaline forms, mainly represented by Buccella peruviana, Cribroelphidium poeyanum, Ammonia parkinsoniana, and Ammonia tepida. This assemblage represents a non-marine unstable environment, with low oxygen levels $(0.3-1.5 \mathrm{~L} / \mathrm{mL})$. In this interval, quantitative analysis and variations in the distribution of the species reflected paleoenvironmental changes between $c a 6880-6640$ and 5590-5430 yrs cal. BP. During the first stage $c a$. $6880-6640$ yrs cal. BP we recognized a brackish environment with the lowest oxygen concentration and low bottom energy. Then, toward $c a 6500-6250 \mathrm{yrs}$ BP, an environment with higher marine influence, increased in oxygen levels and higher bottom energy was detected. This micropaleontological analysis recognized a re-oxygenation event probably derived from the flow of seawater to the area, linked to the sea-level highstand during the Mid-Holocene. Finally, at ca. 6500-5430 yrs cal. BP a gradual transition to lower oxygenation and lower energy in a more restricted environment toward the establishment of brackish conditions such as marsh environment was observed.

\section{Acknowledgements}

This research was performed at the Instituto de Investigaciones en Biodiversidad y Medioambiente INIBIOMA, Consejo Nacional de Investigaciones Científicas y Técnicas (CONICET) and Universidad Nacional del Comahue, Argentina, constitutes a contribution to projects: the National Agency for the Promotion of Science and Technology PICT 2014-1271. The authors are grateful to P. Troyon for preparing SEM samples at Centro Atómico Bariloche. To the anonymous reviewers and editor that with comments and suggestions helped to improve this manuscript.

\section{Funding}

The author(s) disclosed receipt of the following financial support for the research, authorship, and/or publication of this article: This research was supported by the National Agency for the Promotion of Science and Technology (PICT 2014-1271). 


\section{ORCID iD}

Angelica Ballesteros-Prada 3859-3131

\section{References}

Aguirre M (1990) Asociaciones de moluscos bentónicos marinos del Cuaternario tardío en el noreste Bonaerense. Ameghiniana 27(1): 161-177.

Aguirre M (1993) Caracterización faunística del Cuaternario marino del noreste de la Provincia de Buenos Aires. Revista de la Asociación Geológica Argentina 47(1): 31-54.

Aguirre M (1994a) Revisión de las especies de Mactra Linné (Bivalvia) del Cuaternario Bonaerense (Argentina). Aspectos ecológicos y de distribución. Revista Española de Palaeontología 9 (2): 131-144.

Aguirre M (1994b) Type specimens of Quaternary marine bivalves from Argentina. Ameghiniana 31(4): 347-374.

Aguirre M and Whatley R (1995) Late quaternary marginal marine deposits and palaeoenvironments from northeastern Buenos Aires Province, Argentina: A review. Quaternary Science Reviews 14(3): 223-254.

Alperin M, Bernasconi E and Cusminsky G (2008) Asociaciones de foraminíferos bentónicos recientes de la Plataforma Continental Argentina $\left(39^{\circ}-43^{\circ} \mathrm{S}\right.$ y $\left.58^{\circ}-65^{\circ} \mathrm{O}\right)$ analizadas con métodos estadísticos para datos composicionales. Ameghiniana 45(2): 443-461.

Alperin M, Cusminsky G and Bernasconi E (2011) Benthic foraminiferal morphogroups on the Argentine continental shelf. Journal of Foraminiferal Research 41(2): 155-166.

Armstrong HA and Brasier MD (2008) Microfossils. 2nd Ed. London: Blackwell Publishing.

Ballesteros-Prada A and Bernasconi E (2019) Study of marsh foraminifera from the coastal plain of Buenos Aires (Argentina) and its ecological implications. Zootaxa 4560(3): 522-540.

Barmawidjaja D, Jorissen F, Puskaric S et al. (1992) Microhabitat selection by benthic foraminifera in the northern Adriatic Sea. Journal of Foraminiferal Research 22 (4): 297-317.

Berkeley A, Perry C, Smithers S et al. (2007) A review of the ecological and taphonomic controls on foraminiferal assemblage development in intertidal environments. Earth-Science Reviews 83(3-4): 205-230.

Bernasconi E (2020) Ecological study based on the distribution of the recent foraminifers from southeast of Buenos Aires province, Argentinean Continental Shelf. Zootaxa 4821 (1): $135-147$.

Bernasconi E and Cusminsky G (2005) Distribución de Nonionella auris (d'Orbigny) Orden Foraminiferida en el Golfo San Matías, Provincias de Río Negro, Argentina. Ameghiniana 42: 167-174.

Bernasconi E and Cusminsky G (2007) Foraminíferos bentónicos de un testigo del Holoceno de la cuenca del Colorado, Argentina. Ameghiniana 44(2): 271-278.

Bernasconi E and Cusminsky G (2009) Estudio paleoecológico de Foraminíferos de testigos del Holoceno de Golfo Nuevo (Patagonia, Argentina). Geobios 42(4): 435-450.

Bernasconi E and Cusminsky G (2015) Study of the distribution of Elphidium aff. poeyanum (d'Orbigny) and Buccella peruviana (d'Orbigny) from the Colorado basin (South America): Holocene paleoenvironmental inferences. The Holocene 25 (5): 810-819.

Bernasconi E. and Cusminsky G (2020) Calcareous microorganisms as indicator of oceanographic conditions in South West Atlantic Ocean. Journal of Marine Systems 208: 103369.

Bernasconi E, Cusminsky G and Gómez E (2009) Foraminíferos bentónicos del Holoceno del Golfo Nuevo, Argentina: inferencias palaeoclimáticas. (January).
Bernasconi E, Mansilla M and Cusminsky G (2018) Recent benthic foraminifers from the South Atlantic shelf of Argentina. Journal of Foraminiferal Research 48 (3): 210-222.

Bernhard M (1986) Characteristic assemblages and morphologies of benthic foraminifera from anoxic, organic-rich deposits; Jurassic through Holocene. The Journal of Foraminiferal Research 16(3): 207-215.

Bernhard J, Sen Gupta BK and Borne PF (1997) Benthic foraminiferal proxy to estimate dysoxic bottom-water oxygen concentrations: Santa Barbara Basin, U.S. Pacific continental margin. Journal of Foraminiferal Research 27 (4): 301-310.

Bertels-Psotka A and Laprida C (1998a) Ostracoda (Arhropoda, Crustaceae) holocenos del miembro Canal 18, Formación Las Escobas (Holoceno), Provincia de Buenos Aires, República Argentina. Revista Española de Micropalaeontología 1: 129-139.

Bertels-Psotka A and Laprida C (1998b) Ostracodos (Arhropoda, Crustaceae) del miembro Cerro de la Gloria, Formación Las Escobas (Holoceno), Provincia de Buenos Aires, República Argentina. Revista Española de Micropalaeontología 1: 103-129.

Bértola G, Cortizo L and Pastorino S (1998) Delimitación de ambientes costeros en la Bahía Samborombón mediante información satelitaria. V Jornadas Geológicas y Geofisicas Bonaerenses (Mar del Plata) 217-225.

Boltovskoy E and Wright R (1976) Recent Foraminifera.The Hage: Junk, pp. 515.

Boltovskoy E, Giussani G, Watanabe S and Wright R (1980). Atlas of Benthic Shelf Foraminifera of the Southwest Atlantic. The Hague: W. Junk. Publishers, p.147.

Boorman L (2003) Salt marsh review. An overview of coastal salt marshes, their dynamic and sensitivity characteristics for conservation and management. JNCC Report. Available at: http:// jncc.defra.gov.uk/pdf/jncc334.pdf: doi:10.2108/zsj.19.1329.

Brandt D (1989) Taphonomic grades as a classification for Fossiliferous assemblages and implications for palaeoecology. Palaios 4: 303-309.

Brewster-Wingard GL, Ishman SE, Edwards LE et al. (1996) A preliminary report on the distribution of modern fauna and flora at selected sites in north-central and north-eastern Florida Bay. Open-File Report USGS, 96-732.

Buzas M and Gibson T (1969) Species diversity: Benthonic foraminifera in westernnorth Atlantic. Science 163: 72-75.

Cagnoni M (1999) Espartillares de la costa Bonaerense de la República Argentina. Un caso de humedales costeros. In: Malvarèz A (ed) Topicos sobre Humedales Subtropiucales y Templados en Sudamerica. Montevideo: UNESCO, pp.51-67.

Calvo-Marcilese L, Cusminsky G and Gómez E (2011) Asociaciones de foraminíferos bentónicos en secciones holocenas del estuario de Bahía Blanca (Buenos Aires, Argentina): Caracterización palaeoambiental. Ameghiniana 48(2): 210-225.

Calvo-Marcilese L, Pérez Panera J, Cusminsky G et al. (2013) Micropalaeontological record of Holocene estuarine stages in the Bahía Blanca estuary, Argentina. Journal of South American Earth Sciences 45: 147-159.

Calvo-Marcilese L and Pratolongo P (2009) Foraminíferos de marismas y llanuras de marea del estuario de Bahía Blanca, Argentina: Distribución e implicaciones ambientales. Revista Española de Micropalaeontología 41(3): 315-332.

Carol E, Kruse E and Mas-Pla J (2009) Hydrochemical and isotopical evidence of ground water salinization processes on the coastal plain of Samborombón Bay, Argentina. Journal of Hydrology 365(3-4): 335-345.

Carol E, Kruse E and Pousa J (2008) Environmental hydrogeology of the southern sector of the Samborombon Bay wetland, Argentina. Environmental Geology 54(1): 95-102. 
Carol E, Mas-Pla J and Kruse E (2013) Interaction between continental and estuarine waters in the wetlands of the northern coastal plain of Samborombón Bay, Argentina. Applied Geochemistry 34: 152-163.

Cavallotto J, Violante R and Parker G (2004) Sea-level fluctuations during the last 8600 years in the de la Plata river (Argentina). Quaternary International 114(1): 155-165.

Codignotto J and Aguirre M (1993) Coastal evolution, changes in sea level and molluscan fauna in northeastern Argentina during the Late Quaternary. Marine Geology 110(1-2): 163-175.

Colado U, Figini A, Fidalgo F et al. (1995) Los depositos marinos del Cenozoico superior aflorantes en la zona comprendida entre Punta Indio y el río Samborombón, Provincia de Buenos Aires. 4as. Jornadas Geológicas y Geofisicas Bonaerenses, Junín Argentina 1: 151-158.

Corliss B (1985) Microhabitats of benthic foraminifera within deep-sea sediments. Nature 314(6): 435-438.

Corliss B and Chen C (1988) Ecological implications Morphotype patterns of Norwegian Sea deep-sea benthic foraminifera and ecological implications. Geology 16 (August): 716-719.

Cortelezzi C (1993) Sobre la edad de los depósitos de conchillas que afloran en las proximidades de Puente de Pascua (Partido de Castelli, Prov. de Buenos Aires). $12^{\circ}$ Congreso Geológico Argentino y $2^{\circ}$ Congreso de Exploración de Hidrocarburos 249-251.

Cusminsky G, Bernasconi E and Calvo-Marcilese L (2009) Holocene benthic foraminifera from Bahía Blanca estuary: A review and update of systematic and palaeoenvironmental aspects. Holocene 19(8): 1221-1231.

Eichler P, Eichler B, Gupta B et al. (2012) Foraminifera as indicators of marine pollutant contamination on the inner continental shelf of southern Brazil. Marine Pollution Bulletin 64(1): 22-30.

Fidalgo F, Colado U and De Francesco F (1973) Sobre ingresiones marinas cuaternarias en los partidos de Castelli, Chascomús y Magdalena (Pcia. de Buenos Aires). $5^{\circ}$ Congreso Geológico Argentino Córdoba 3 : 227-240.

Fisher R, Corbet A and Williams CB (1943) The relation between the number of species and the number of individuals in a random sample of an animal population. The Journal of Animal Ecology 12 (1): 42.

Fucks E, Schnack E and Aguirre M (2010) Nuevo ordenamiento estratigráfico de las secuencias marinas del sector continental de la Bahía Samborombón, provincia de Buenos Aires. Revista de la Asociacion Geologica Argentina 67 (1): 27-39.

Fundación Vida Silvestre Argentina (2013) Aportes para abordar la adaptación al cambio climático en la bahía samborombón. $1-257$.

Garreaud R, Vuille M, Compagnucci R and Marengo J (2009) Present-day South American climate. Palaeogeography, Palaeoclimatology, Palaeoecology 281(3-4): 180-195.

Goldstein S (2002) Foraminifera: A biological overview. In: Sen Gupta BK (ed) Modern Foraminifera. Dordrech: Kluwer Academic Publishers, 7-37.

Goldstein S and Watkins G (1999) Taphonomy of salt marsh foraminifera: An example from coastal Georgia. Palaeogeography, Palaeoclimatology, Palaeoecology 149(1-4): 103-114.

Gómez EA, Martínez D, Borel MD et al. (2005) Submarine evidences of Holocene sea-level fluctuations in the Bahia Blanca estuary, Argentina. Journal of South American Earth Sciences 20: $139-155$.

Gooday A (1993) Deep-sea benthic foraminiferal species which exploit phytodetritus: Characteristic features and controls on distribution. Marine Micropalaeontology 22(3): 187-205.

Guerrero R, Acha E, Framiñan M et al. (1997) Physical oceanography of the Rio de la Plata Estuary, Argentina. Continental Shelf Research 17(7): 727-742.
Grimm E (2004) Tilia Software 2.0.2, Illinois State Museum Research and Collection Center Springfield.

Hammer O, Harper D and Ryan P (2001) Past: Palaeontological statistics software package for education and data analysis. Palaeontologia Electronica 4 (1) 4: 9.

Haynes JH (1981) Foraminifera. London and Basingstoke: MacMillan Publishers Ltd, pp. 433.

Hayward B, Neil H, Carter R et al. (2002) Factors influencing the distribution patterns of recent deep-sea benthic foraminifera, east of New Zealand, Southwest Pacific Ocean. Marine Micropalaeontology 46(1-2): 139-176.

Hogg AG, Hua Q, Blackwell PG et al. (2013) SHCal13 Southern Hemisphere calibration, 0-50,000 years cal BP. Radiocarbon 55: 1889-1903.

Ishman SE, Brewster-Wingard GL, Willard D et al. (1996) Preliminary palaeontologic report on core T-24, Little Madeira Bay, Florida. Open-File Report USGS, 96-543.

Isla F (1989). Holocene sea level fluctuations in the southern hemisphere. Quaternary Sciences Review 8: 359-368 (Kidlington).

Isla F, Rutter N and Zarate M (2000) La transgresión belgranense en Buenos Aires. Una revisi6n a cien años de su definicion. Revista Cuaternario y Ciencias Ambientales 4: 3-14.

Jorissen F, Stigter H and Widmark J (1995) A conceptual model explaining benthic foraminiferal microhabitats. Marine Micropalaeontology 26: 3-15.

Kaiho K (1994) Benthic foraminiefera dissolved-oxygen index and dissolved-oxygen levels in the modern ocean. Geology 22: 719-722.

Kaiho K (1999) Effect of organic carbon flux and dissolved oxygen on the benthic foraminiferal oxygen index (BFOI). Marine Micropalaeontology 37(1): 67-76.

Karlsen AW, Cronin TM, Ishman S et al. 2000 Historical trends in Chesapeake Bay dissolved oxygen based on benthic foraminifera from sediment cores. Estuaries 23: 488-508.

Koehn-Zaninetti L (1982) Les Foraminifères des marais salants de Salin-de-Giraud (Sud de la France): Milieu de vie et transport dans le salin, comparaison avec les micro-faunes marines. Géologie Méditerranéenne 9(4): 447-470.

Laprida C (1997) Micropalaeontología (Ostracodos y foraminiferos) y paleoecología del Cuaternario Tardio del Noroeste de la Provincia de Buenos Aires, República Argentina. Universidad de Buenos Aires, PhD thesis.

Laprida C (1998) Micropalaeontological assemblages (Foraminiferida and Ostracoda) from Late Quaternary marginal marine environments (Destacamento Rio Salado Formation), Salado Basin, Argentina. Revue de Paleobiologie 17(2): 461478.

Laprida C and Bertels-Psotka A (2003) Foraminifères benthiques et paléoécologie d'un falun holocène, Bassin du Salado, Argentine. Geobios 36(5): 559-572.

Laprida C, Chandler D, Mercau J et al. (2011) Modern foraminifera from coastal settings in northern Argentina: Implications for the palaeoenvironmental interpretation of Mid Holocene littoral deposits. Revista Mexicana de Ciencias Geologicas 28(1): 45-64.

Laprida C, Chapori N, Violante R et al. (2007) Mid-Holocene evolution and palaeoenvironments of the shoreface-offshore transition, north-eastern Argentina: New evidence based on benthic microfauna. Marine Geology 240(1-4): 43-56.

Loeblich A and Tappan H (1992) Present status of foraminiferal classification, in Studies in Benthic Foraminifera. In: Takayanagi Y and Saito T (eds) Proceedings of the Fourth International Symposium on Benthic Foraminifera. Tokyo: Tokai University Press, 93-102.

Luengo MS (2019) Vegetación y ambientes del Holoceno en el sector continental de la Bahía Samborombón, provincia de 
Buenos Aires: cambios del nivel del mar. Universidad Nacional de La Plata. PhD thesis, 178 pp.

Luengo M, Bernasconi E, Vilanova I et al. (2018) Past environmental changes during the Late Holocene sea-level fall (last $2.7 \mathrm{Ka}$ ) at Bahía Samborombón, NE coastal plain (Argentina). Journal of South American Earth Sciences 85(May): 362-373.

Márquez M (2019) Holocene foraminifera of the southeast of the Pampa coastal plain, Argentina. Journal of South American Earth Sciences 94(February): 102215.

Márquez M and Ferrero L (2011) Palaeoecology of foraminifera from a holocene core recovered in the coastal plain of mar Chiquita Lagoon, Buenos Aires, Argentina. Ameghiniana 48(3): 289-304.

Márquez M, Ferrero L and Cusminsky GC (2016) Holocene palaeoenvironmental evolution of the Pampa coastal plain (Argentina) based on calcareous microfossils. Revista Brasileira de Paleontologia 19(1): 25-40.

Martin R (1999) Taphonomy A Process Approach. New York: Cambridge University Press, $508 \mathrm{pp}$.

Murray JW (1991) Ecology and Palaeoecology of Benthic Foraminifera. Harlow: Longman, p.397.

Murray J (2006) Ecology and Applications of Benthic Foraminifera. Cambridge: Cambridge University Press. The Edinburgh Building. 426 pp.

Parker G (1990) Estratigrafía del Río de la Plata. Revista de la Asociación Geológica Argentina. Revista de la Asociación Geológica Argentina 45: 193-204.

Pregnolato L, Viana R, Passos C et al. (2018) Ammonia-Elphidium Index as a proxy for marine pollution assessment, northeast Brazil/O uso do índice Ammonia-Elphidium como proxy para a avaliação da poluição marinha do nordeste brasileiro. Journal of Sedimentary Environments 3(3): 176-186.

Prieto A, Mourelle D, Peltier W et al. (2017) Relative sea-level changes during the Holocene in the Río de la Plata, Argentina and Uruguay: A review. Quaternary International 442: 35-49.

Reimer PJ, Bard E and Bayliss A (2013) IntCal13 and Marine13 radiocarbon age calibration curves $0-50,000$ years cal BP. Radiocarbon 55 (4): 1869-1887.

Richiano SN, Varela A, D’Elias L et al. (2012) Evolución paleoambiental de cordones litorales holocenos durante una caída del nivel del mar en la evolución palaeoambiental de cordones litorales. Latin American Journal Sedimentology and Basin Analysis 19(2): 105-124.

Schnack E, Isla F, De Francesco F et al. (2005) Estratigrafía del cuaternario marino tardío en la provincia de buenos aires. Geología y Recursos Minerales de la provincia de Buenos Aires 16 Congreso Geológico Argentino 159-182.

Sen Gupta B (1999) Systematics of modern Foraminifera. In: Sen Gupta B (ed) Modern Foraminifera. Dordrech: Kluwer Academic Publishers, 3-7.
Sen Gupta B and Barun K (1999) Foraminifera in marginal marine environments. In: Sen Gupta B (ed) Modern Foraminifera. Dordrech: Kluwer Academic Publishers, 151-159.

Sen Gupta B and Machain-Castillo M (1993) Benthic foraminifera in oxygen-poor habitats. Marine Micropalaeontology 20(3-4): 183-201.

Sen Gupta B and Platon E (2006) Tracking past sedimentary records of oxygen depletion in coastal waters: Use of the Ammonia-Elphidium Foraminiferal index. Journal of Coastal Research 3(39): 1351-1355.

Sen Gupta B, Turner R and Rabalais N (1996) Seasonal oxygen depletion in continental-shelf waters of Louisiana: Historical record of benthic foraminifers. Geology 24(3): 227-230.

Servicio de Hidrografía Naval (2002) Derrotero Argentino. Parte I. Río de la Plata. Buenos Aires Publ. H-201.

Smart C (2002) Environmental applications of deep-sea benthic foraminifera. In: Haslett S (ed) Quaternary Environmental Micropalaeontology. London: Arnold Publishers, pp.14-58.

Stuiver M and Reimer PJ (1993) Extended 14C data base and revised CALIB $3.0{ }^{14} \mathrm{C}$ age calibration program. Radiocarbon 35(1): 215-230.

Teodoro A, Duleba W, Gubitoso S et al. (2010) Analysis of foraminifera assemblages and sediment geochemical properties to characterise the environment near Araça and Saco da Capela domestic sewage submarine outfalls of São Sebastião Channel, São Paulo State, Brazil. Marine Pollution Bulletin 60(4): 536-553.

Usera J and Blázquez-Morilla A (1997) Influencia del sustrato en la distribución de los foraminíferos bentónicos de la plataforma continental interna entre Valencia y Alicante (España). Revista española de micropalaeontología 29(2): 85-104.

Vilanova I and Prieto A (2012) Llanuras Costeras De La Bahía Samborombón $\left(\sim 35,5^{\circ} \mathrm{S}\right)$, Argentina. Amenghiniana 49(3): 303-318.

Violante R and Parker G (2000) El Holoceno en las regiones marinas y costeras del nordeste de Buenos Aires. Revista de la Asociación Geológica Argentina 55: 337-351.

Violante R and Parker G (2004) The post-last glacial maximum transgression in the de la Plata River and adjacent inner continental shelf, Argentina. Quaternary International 114(1): 167-181.

Violante R, Parker G and Cavallotto J (2001) Evolución de las llanuras costeras del este bonaerense entre la bahía Samborombón y la laguna Mar Chiquita durante el Holoceno. Revista de la Asociación Geológica Argentina 56 (1): 51-66.

Wang P and Murray JW (1983). The use of foraminifera as indicators of tidal effects. Marine Geology 51: 239-250.

Wright CA (1972) Foraminiferids from the London Clay at Lower Swanwick and their palaeoecological interpretation. Proccedings Geolology Association 83(3): 337-348. 